\title{
Ancient mitochondrial genomes recovered from small vertebrate bones through minimally destructive DNA extraction: phylogeography of the New Zealand gecko genus Hoplodactylus.
}

\author{
Lachie Scarsbrook $^{1}$, Alexander Verry ${ }^{1}$, Kerry Walton ${ }^{1}$, Rodney Hitchmough ${ }^{2}$, and Nic \\ Rawlence $^{1}$ \\ ${ }^{1}$ Otago Paleogenetics Laboratory \\ ${ }^{2}$ Department of Conservation
}

December 23, 2021

\begin{abstract}
Methodological and technological improvements are continually revolutionizing the field of ancient DNA. Most ancient DNA extraction methods require the partial (or complete) destruction of finite museum specimens, which disproportionately impacts small or fragmentary subfossil remains, and future analyses. We present a minimally destructive ancient DNA extraction method optimized for small vertebrate remains. We applied these methods to detect lost mainland genetic diversity in the large New Zealand diplodactylid gecko genus Hoplodactylus, which is presently restricted to predator-free island sanctuaries. We present the first mitochondrial genomes for New Zealand diplodactylid geckos, recovered from 19 modern, six historic/archival (1898 to 2011) and 16 Holocene Hoplodactylus duvaucelii sensu latu specimens, and one modern Woodworthia sp. specimen. No obvious damage was observed in post-extraction micro-CT reconstructions. All 'large gecko' specimens examined from extinct populations were found to be conspecific with extant Hoplodactylus species, suggesting their large relative size evolved only once in the New Zealand diplodactylid radiation. Phylogenetic analyses of Hoplodactylus samples recovered two genetically (and morphologically) distinct North and South Island clades, probably corresponding to distinct species. Finer phylogeographic structuring within Hoplodactylus spp. highlighted the impacts of Late-Cenozoic biogeographic barriers, including the opening and closure of Pliocene marine straits, fluctuations in size and suitability of glacial refugia, and eustatic sea-level change. Recent mainland extinction obscured these signals from the modern tissue derived data. These results highlight the utility of minimally destructive DNA extraction in genomic analyses of less well studied small vertebrate taxa, and the conservation of natural history collections.
\end{abstract}

\section{Hosted file}

Main_Text.docx available at https://authorea.com/users/452385/articles/550475-ancientmitochondrial-genomes-recovered-from-small-vertebrate-bones-through-minimallydestructive-dna-extraction-phylogeography-of-the-new-zealand-gecko-genus-hoplodactylus 


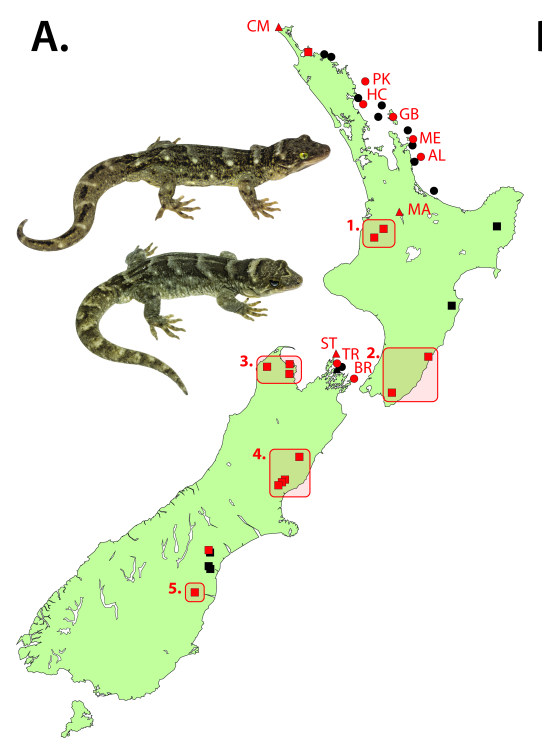

B. Pre-Extraction

Post-Extraction
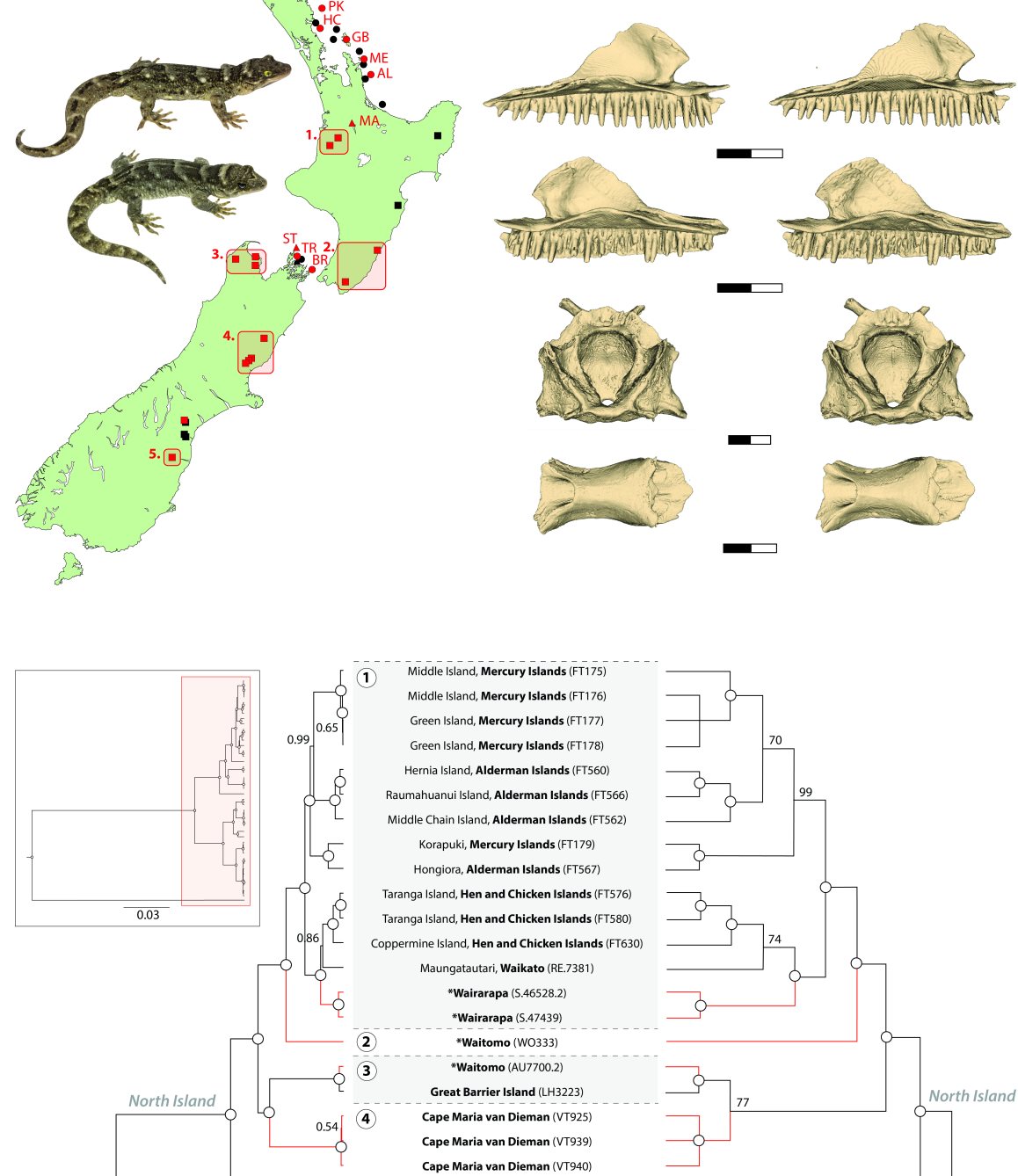

(5) Aorangi Island, Poor Knights Islands (CD1032)

Middle Trios Island, Trios Islands (FT2046)

\begin{tabular}{|cc}
\hline 56 Middle Trios Island, Trios Islands (FT2046) \\
North Trios Island, Trios Islands (FT2047) \\
North Brother Island, Brothers Islands (FT277)
\end{tabular}

North Brother Island, Brother Island, Brothers Islands (FT278)

North Brother Island, Brothers Islands (FF2908)

North Brother Island, Brothers Islands (FT2909)

*northwest South Island (S.38813.2)

Stephen's Island (VT949)

*North Canterbury (S.33501)

*North Canterbury (5.33703.11)

*North Canterbury (5.33703.7)

*North Canterbury (5.33703.10

*North Otago (VT807a)

*North Canterbury (5.33703.1)

*North Otago (VT3333)

*North Otago (VT3332)

*North Otago (VT719a)

*North Otago (VT3331)

*North Otago (VT807b)

$\overline{0.01 \text { subs/site }}$

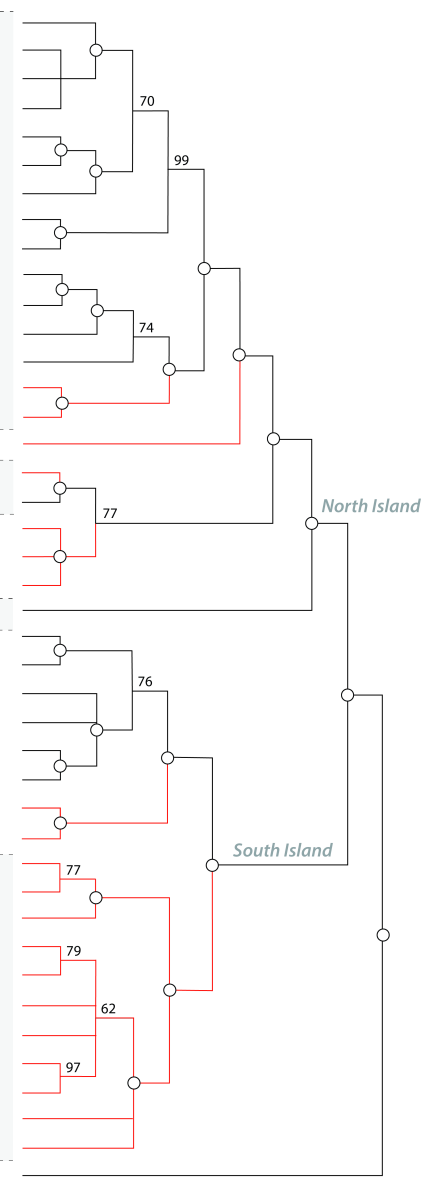




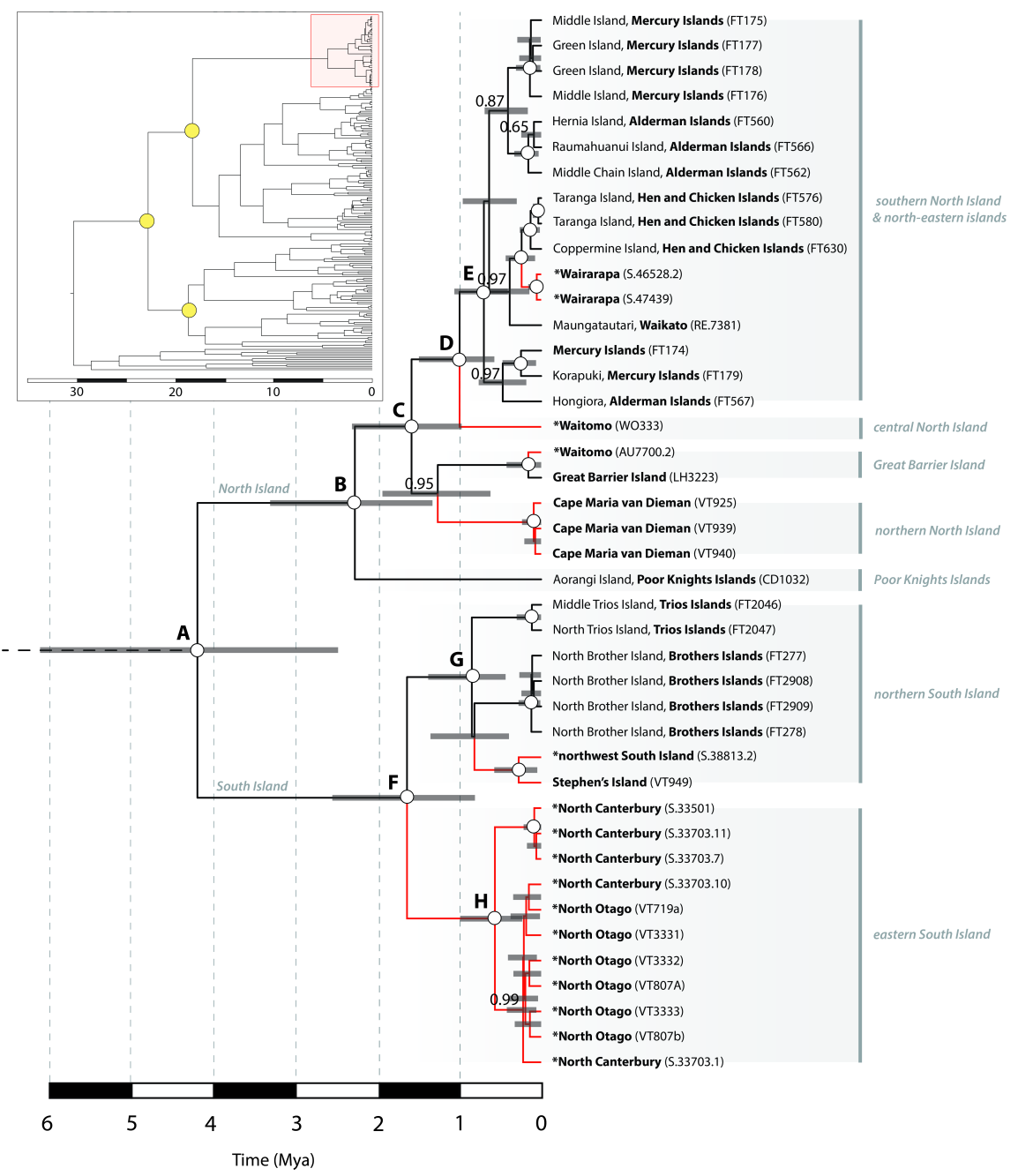




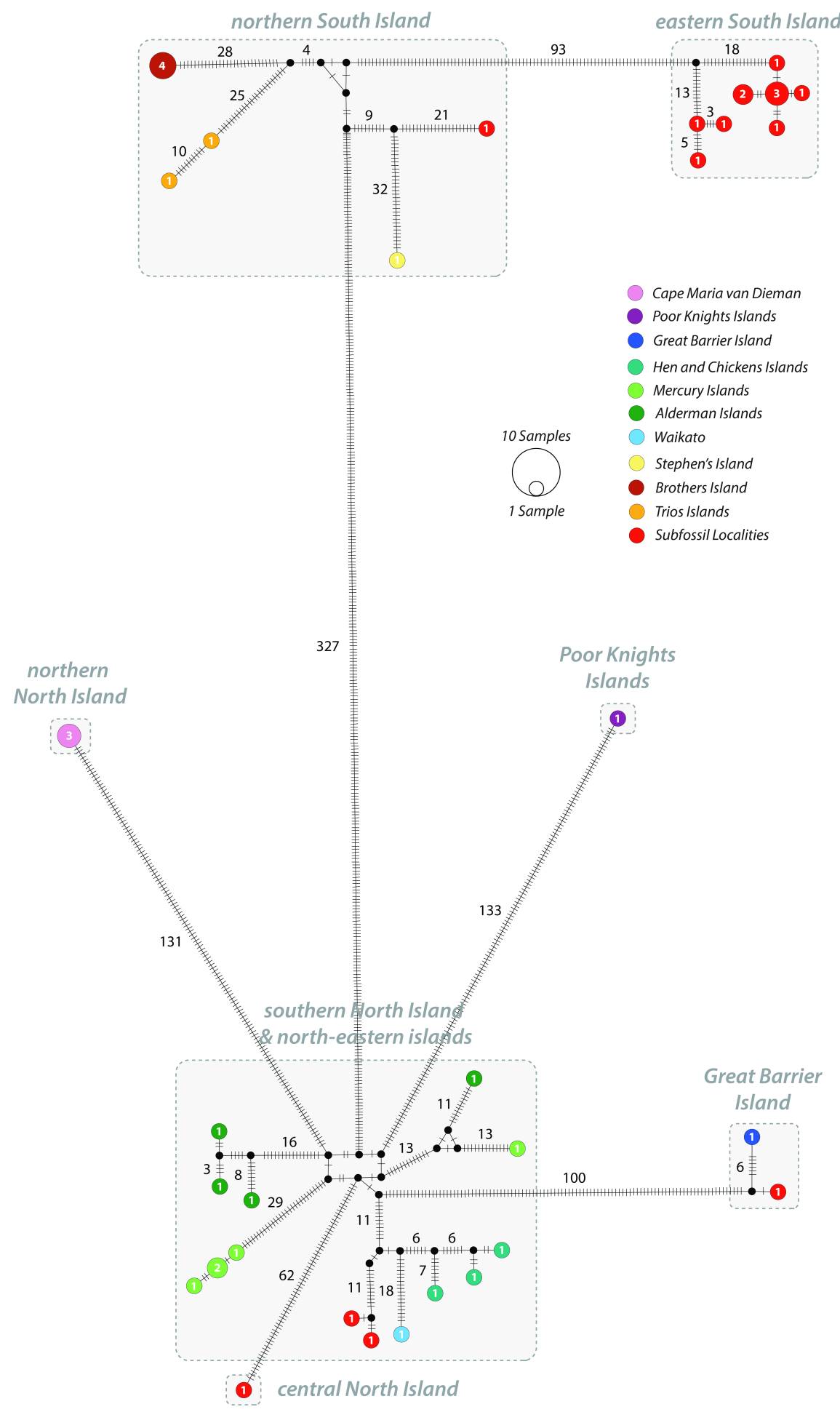




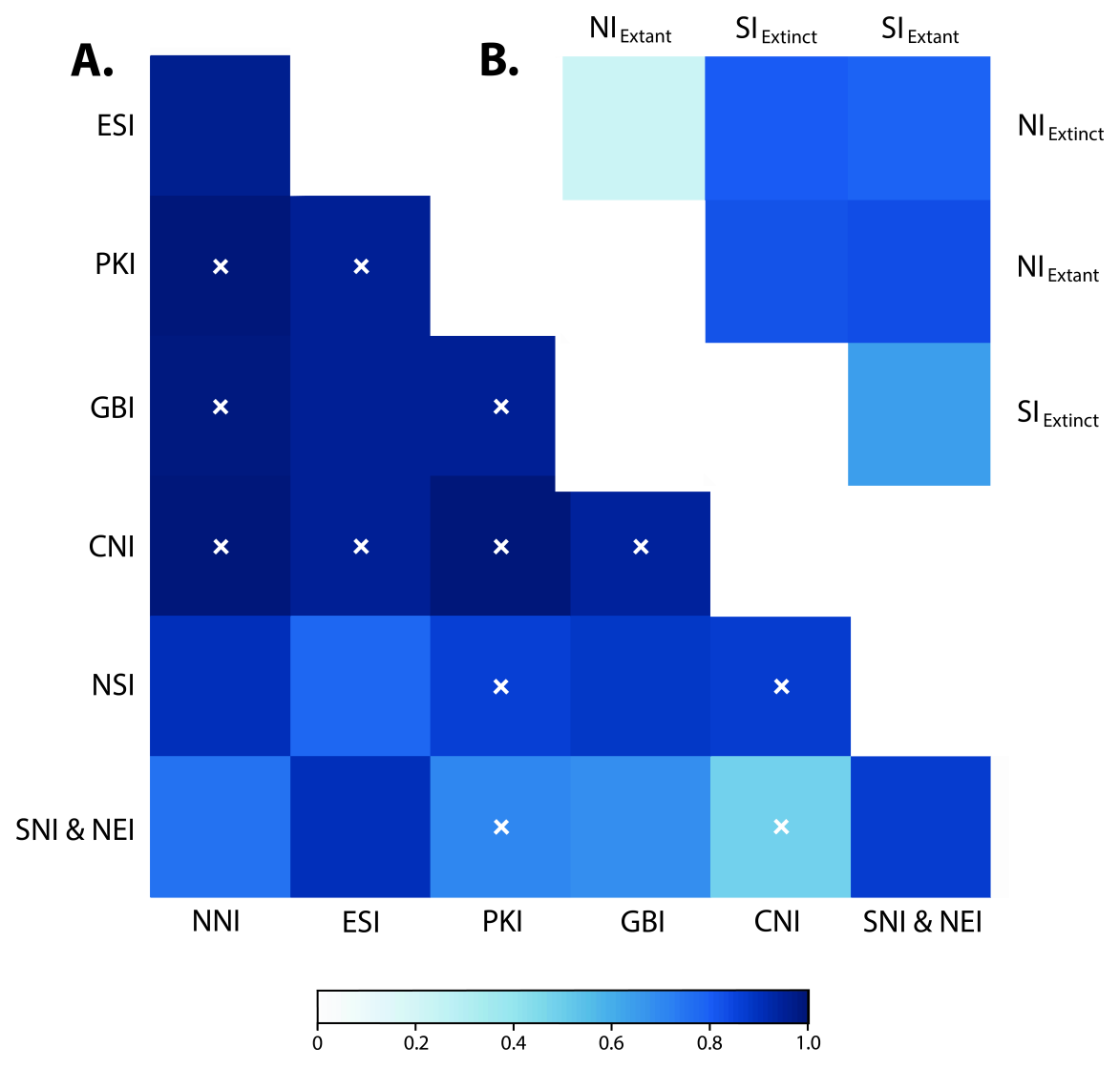

